\title{
Antimicrobial activity of the ethanolic extract of Guettarda sericeaagainst oral streptococci
}

\author{
Edson Teixeira" ${ }^{*}$, Érica Rabelo ${ }^{1}$, Bruno Silva', Luiz Nascimento Neto ${ }^{1}$, Francisco Arruda ${ }^{1}$, Hélcio Santos ${ }^{2}$, \\ Maria Albuquerque ${ }^{2}$, Paulo Bandeira ${ }^{2}, K_{\text {Kyria Nascimento }}{ }^{1}$, Benildo Cavada', Jorge Martins ${ }^{3}$ \\ From 5th Congress of the Brazilian Biotechnology Society (SBBIOTEC) \\ Florianópolis, Brazil. 10-14 November 2013
}

\section{Background}

The genus Guettarda (Rubiaceae) comprises plants widely distributed in tropical areas [1]. Regarding the Guettarda sericea species, the literature shows that there is a lack of botanical and phytochemicals studies [2]. Thus, the present study aimed to evaluate the antibacterial effect of ethanol extract of leaves of G. sericea (EEFGS) on the growth of Streptococcus oralis ATCC 10557 and S. salivarius ATCC 7073 in both the planktonic and biofilms states.

\section{Methods}

Different methods were employed to verify the antimicrobial potential. Among these are the determination of minimum inhibitory concentration (MIC) determination of the death curve and evaluation of minimum bactericidal concentration (MBC) [3]. Furthermore, quantification of biomass and the number of viable cells of the biofilm were performed [4]. The negative and positive controls used in all assays were respectively $4 \%$ DMSO and chlorhexidine gluconate. To determine the toxicity of EEFGS, it was used the toxicity test on Artemia nauplii [5].

\section{Results and conclusions}

The data showed that the extract has a remarkable antimicrobial effect, able to inhibit the growth of planktonic and development of biofilms of $S$. oralis strain until the concentration of $62.5 \mu \mathrm{g} \cdot \mathrm{mL}^{-1}$. Regarding the toxicity, it was observed that death of Artemia nauplii occurred at higher concentrations than those that exhibited antibacterial effect. It can be concluded that EEFGS can be used as agents for the control of biofilm formation of $S$. oralis. In addition, complementary methodologies that seek purification of the active compounds and their cytotoxic effects on eukaryotic cells need to be held, aiming its use as an herbal agent.

\section{Authors' details}

${ }^{1}$ Federal University of Ceará, Brazil. ${ }^{2}$ Acaraú Valley State University, Sobral, Ceará, Brazil. ${ }^{3}$ Federal University of Pelotas, Brazil.

\section{Published: 1 October 2014}

\section{References}

1. Achille F, Motley TJ, Lowry II PJ, Jérémie J: Polyphyly in Guettarda L. (Rubiaceae, Guettardeae) based on nrDNA ITS sequence data. Annals of the Missouri Botanical Garden 2006, 93(1):103-121.

2. Agra MF, França PF, Barbosa-Filho JM: Synopsis of the plants known as medicinal and poisonous in Northeast of Brazil. Revista Brasileira de Farmacognosia 2007, 17(1):114-140.

3. Clinical and Laboratory Standards Institute: Performance standards for antimicrobial susceptibility testing, twenty informational supplement, approved standard MS100-S20. Wayne, PA: CLSl; 2010.

4. Stepanovic S, Vukovic D, Dakic I, Savic B, Svabic-Vlahovic M: A modified microtiter-plate test for quantification of staphylococcal biofilm formation. J Microbiol Methods 2000, 40(2):175-9.

5. Veiga LF, Vital N: Testes de toxicidade aguda com o microcrustáceo Artemia sp. In Métodos em Ecotoxicologia Marinha. Aplicações no Brasil. Artes Gráficas e Indústria Ltda: São Paulo;Nascimento IA, Sousa ECPM, Nipper M 2002:

doi:10.1186/1753-6561-8-S4-P54

Cite this article as: Teixeira et al:: Antimicrobial activity of the ethanolic extract of Guettarda sericeaagainst oral streptococci. BMC Proceedings 2014 8(Suppl 4):P54.

${ }^{1}$ Federal University of Ceará, Brazil

Full list of author information is available at the end of the article 